\title{
Teacher salary differentials using Purchasing Power Parity (PPP): a South African perspective as both a 'source' and 'destination' country
}

\section{Gavin George and Bruce Rhodes}

\begin{abstract}
Teacher migration is a problem for developing countries as it impacts on delivery of quality education. The potential to earn higher incomes remains the most common factor driving teacher migration. This study seeks to investigate how the South African teacher salary structure compares with the equivalent salary structure in six prominent migrating countries whilst highlighting the economic appeal of South Africa from a Zimbabwean teacher perspective. Using a representative basket of commonly bought goods (including food, entertainment, fuel and utilities), a purchasing power parity (PPP) ratio is used to equalise the international price of buying that basket. Our study makes comparisons, using a PPP index, and allows the identification of real differences in salaries for our selected countries (South Africa, United States, United Kingdom, Canada, Australia, New Zealand, Japan and Zimbabwe) for selected teaching categories. Even when controlling for differences in the cost of living, the incentive for a South African teacher to seek work overseas remains strong and increases with career experience. A worrying conclusion for South Africa concerned with keeping its experienced teachers is that as more human capital is gained by experience, the greater the incentive to emigrate.
\end{abstract}

\section{Background}

All countries seek to ensure they provide a suitable standard of education as part of their developmental goals. Importantly, possessing an adequate supply of teachers is instrumental in ensuring the provision of quality education (Mugano, 2010). Maintaining an adequate supply of quality teachers is thus paramount, but can be a challenge for some developing countries. Increased globalisation has resulted in the movement of skilled labour, including teachers, from developing to developed or economically stronger countries. It is these emigrating teachers which hamper the 'source' countries' ability to provide quality education, thus compromising their own developmental goals (South African Council for Educators (SACE), 2011). 
Skilled labour is enticed from these 'source' countries for socio-economic and career gains. Skilled professionals are migrating from developing countries to fill the gaps in the labour market in developed countries. Research has suggested that this phenomenon is particularly damaging to the economic growth of those developing countries affected by migration (Asmal, 2001; Louw, 2001a, b).

In many developed countries the pool of teachers is ageing due to an inability to attract young people into the profession. Teacher shortages peaked in the late 1990s and early 2000s in many developed countries, including the United Kingdom (UK), United States (US), Canada, Australia and Netherlands (Van Leeuwan, 2001). These shortages were as a result of the ageing teaching workforce and, as was the case in the UK, the relative decline of salaries and working conditions of teachers, which resulted in inadequate recruitment and diminishing retention rates (Smithers and Robinson, 2001). Conservative estimates revealed that there was a national shortage of 40,000 teachers in the UK (Ochs, 2003). Such shortages lead governments to actively recruit foreign teachers (Naidu, 2001). These recruitment drives were undertaken by agencies and targeted developing countries where English was an official language (Manik, Maharaj and Sookrajh, 2006). Research suggests that the more qualified and more experienced teachers were targeted by recruitment efforts (Ochs, 2003). Whilst this practice peaked in the late 1990s and early 2000s, teachers will continue to be lured to countries where a financial benefit can be accrued.

\section{Teaching in South Africa}

Appleton, Sives and Morgan (2006a) argue that the demand and supply of teachers is determined by government policies. Migration in South Africa (SA) was provided impetus by the perception in the 1990s that there was an oversupply of teachers in the country. In 1997 SA introduced a moratorium which lasted until 2000, restricting newly qualified teachers to temporary positions within the education department. These conditions created fertile ground for those countries experiencing shortages in the supply of educators, to take advantage and lure SA teachers abroad (Appleton, Sives and Morgan, 2006a). Teacher attrition, fuelled by teacher migration to pursue socioeconomic and career opportunities abroad (Bertram, Appleton, Muthukrishna and Wedekind, 2006; Manik, Maharaj and Sookrajh, 2006), was exacerbated 
by high incidences of HIV/AIDS and subsequent teacher mortality (Shisana, Peltzer, Zungu-Dirwayi and Louw, 2005).

This emerging teacher crisis was illustrated by numerous studies with Morgan, Sives and Appleton (2006) estimating that the total teacher population in South Africa was approximately 400,000 in 2006 and that South Africa needed to recruit 17,000 to 20,000 teachers per year if learner-toeducator ratios of 40:1 for primary schools and 35:1 for secondary schools were to be maintained. Despite this warning, teacher training output was only around 9,000 newly qualified teachers per year. Low production rates of teachers were compounded by high attrition rates with the Education Minister concluding in 2004 that each year in South Africa 17,000 teachers were leaving the teaching profession (Mkhize, 2004). A study in 2005 showed that $27.4 \%$ of final-year South African student teachers were planning to teach abroad (Bertram et al., 2006).

In recognition of the increased prevalence of teacher migration, especially to the UK, the South African government's response in 2001 was to call for the regulation of teacher recruitment (Gilbey, 2001). In the absence of any regulatory force this had little effect. In September 2004, amidst broader concerns about teacher recruitment from developing countries within the Commonwealth, the SA Minister of Education and 22 Commonwealth states signed a protocol on teacher recruitment. This was to provide an ethical guideline for the recruitment of teachers at an international level (Manik, Maharaj and Sookrajh, 2006).

In an attempt to counter outward migration SA sought to recruit teachers from abroad to fill vacant posts, especially in the fields of Mathematics and Science, and especially in the rural areas (Ranga, 2015). SA actively recruited teachers from India, Zimbabwe, Singapore, Malaysia and Uganda (De Villiers, 2004). Zimbabwean teachers were identified as an under-utilised resource with Forde (2007) estimating that approximately 10,000 Zimbabwean trained teachers were living in SA in 2006, with 4,000 qualified Mathematics and Science teachers among them. A further study (SACE, 2011) suggested there remained an increasing number of teachers from other African countries (e.g., Lesotho, Zimbabwe, Zambia, etc.) immigrating into South Africa due to the country's relative economic prosperity, political stability and promise of better working conditions and income. 
Despite the availability of this teaching resource a policy of restriction was implemented through the use of a system of work and residence permits (Wentzel and Tlabela, 2006). Furthermore, a foreign qualified teacher was required to be professionally registered for teaching in SA, resulted in an additional barrier. According to the Commonwealth Secretariat (2010), thousands of teachers from Zimbabwe are unable to work as teachers as their qualifications are not recognised by South African qualifications agencies. However, 2012 PERSAL data indicates that there are 6214 foreign teachers teaching in public schools within South Africa, constituting $2 \%$ of the total teaching workforce in public schools. Zimbabwean teachers make up $68 \%$ of the total foreign teaching workforce (Department of Basic Education (DBE), 2013).

\section{Teacher migration}

The 'Big Five' destination countries for SA teachers include the US, UK, Australia, New Zealand and Canada (Sunday Times, 08-12-2002). In the late 1990s Statistics South Africa estimated that on average 1,000 skilled people were leaving SA every month (Harichunder, 2001). A study of emigration to the UK, US, New Zealand, Canada and Australia suggested that close to a quarter of a million South Africans have settled in these countries between 1989 and 1997 (Louw, 2001). There are seemingly no reliable figures on exactly how many teachers are leaving South Africa, or for how long they are staying abroad. However, figures from the British Department of Home Affairs illustrate the stark rise in teacher migration. Only 20 work permits were issued in 1997-1998 for South African teachers to teach in the UK (Jansen, 2002), but between 2001 and 2003 4,702 work permits were approved by the UK for SA teachers (Caravatti, Lederer, Lupico and Meter, 2014). Africans constitute the majority of foreign teachers in the United Kingdom (Appleton et al. 2006a; Manik, Maharaj and Sookrajh, 2006) with South Africa listed as the largest foreign provider of teaching staff in the United Kingdom (Kok, Gelderblom, Oucho and Van Zyl, 2006; Morgan, Sives and Appleton, 2006; Caravatti et al., 2014). Appleton, Sives and Morgan (2006a) suggest that between $0.5-4 \%$ of all South African trained teachers work abroad. Of concern is that the research further suggests that $48 \%$ of practicing teachers in South Africa intended to migrate and $27 \%$ of student teachers were considering migrating upon graduation. 


\section{Reasons for teacher migration}

The SA education system has been blamed for the disenchantment SA teachers have with the profession. Arends and Phurutse (2009) suggest the problem lies with the lack of formal structures, policies and strategies for teacher retention. A growing desire from teachers to leave the profession is further aggravated by low morale, low levels of job satisfaction, unpleasant working conditions (Shalem and Hoadley, 2009) and high levels of job stress correlated with time pressures, educational changes, administrative problems, educational systems, professional distress and pupil misbehaviour (Peltzer, Shisana, Zuma,Van Wyk and Zungu-Dirwayi, 2009).

Manik, Maharaj and Sookrajh (2006) unpack the problems with the educational policies further, and suggests that the implementation of outcomes-based education (OBE) along with the application of the postprovisioning norm (PPN) or teacher-pupil ratio in schools to determine additional teachers, and the instability faced by unprotected temporary educators (UTEs) have played a big role in unsettling teachers resulting in many exploring the option of teaching abroad. Further to these changes, teachers were concerned about their limited career mobility, poor management and increased workloads (Manik, Maharaj and Sookrajh 2006).

Given the systemic problems described above, the option of migrating must appear inviting. International migration becomes desirable when teachers consider the large wage differentials between potential earnings abroad and domestic wage offerings (Appleton, Morgan and Sives, 2006b). For example, Morgan, Sives and Appleton (2006) observed that South Africans were able to earn three to four times more by teaching in the UK than by staying in their own country.

Further studies have confirmed that the dominating motivator for migration was the opportunity to earn a higher salary and to travel, followed by professional development (Rasool, Botha and Bisschoff, 2012). These 'pull' factors (i.e., the lure of the destination countries) appeared to play a stronger role than the 'push' factors (i.e., the negative aspects of teaching in SA), including career progression opportunities, the high crime rate and bad working conditions (Ochs, 2003; De Villiers, 2004; Appleton, Sives and Morgan, 2006a). 
Indeed all teachers' salaries are relative, and South Africa benefits from the fact that its salaries are higher relative to those offered by its neighbouring countries. South Africa has long been attracting teachers from the rest of the African continent and projections point towards the continuation of such a pattern of migration as long as South Africa remains economically dominant and attractive in Africa (Wentzel, Viljoen and Kok, 2006). In the financial year of 2009/2010, the South African Council for Educators (SACE) registered 28,723 new educators, and foreign educators registered made up approximately $28 \%$ of registered educators; however, the registration of foreign teachers was on a provisional annually renewable basis (SACE, 2010).

The movement of Zimbabwean teachers into South Africa has been attributed, in part, to the political instability in their country of origin. While politics may be a reason, research shows that economic reasons are more likely to serve as an impetus, primarily because Zimbabwean teachers who come to South Africa continue to send remittances to their families back home and commute back and forth between Zimbabwe and South Africa (Makina, 2007; Mosala, 2008).

This study seeks to investigate how the South African school teacher wage structure compares with the equivalent wage structure in six prominent migrating countries whilst highlighting the economic appeal of South Africa from a Zimbabwean teacher perspective. Careful attention is made to differences in the cost of living between countries using standard purchasing power parity (PPP) indices.

\section{Methods}

The extant literature has only examined actual salaries for teachers offered in selected, popular emigrant countries. For more informed comparisons on earnings, we require a purchasing power parity (PPP) index. Using a representative basket of commonly bought goods (including food, entertainment, fuel and utilities), the PPP is an exchange rate between two currencies that equalises the international price of buying that basket.

Foreign salaries expressed in national currency units were converted to the rand equivalent using purchasing power parity ratios published by the 
International Monetary Fund (IMF). The PPP is essentially an exchange rate between two countries that equalises the cost of living. It is founded on the principle of an international dollar. This is a purely hypothetical currency where one international dollar (earned in another country) has the same purchasing power as one US dollar earned and spent in the US. The PPP for the US is set at 1.0 and acts as a baseline to compare all other countries. Examining the cost-of-living adjusted salaries for each of our selected countries allows the identification of financial incentives to emigrate within a given teacher category.

The international dollar PPP salaries are presented relative to South Africa and are shown in Table 2. Whilst a useful comparator, the PPP methodology does have the problem of finding a basket of goods that is wholly comparable across selected countries where availability and indeed quality are not constant. In general this is not a strong enough concern to warrant an alternative methodology. Income tax rates can also make salary comparisons problematic yet comparing gross with net earnings across countries made little or no difference to the pattern of results reported below. As such the PPP comparisons remain valid.

\section{Selected teacher categories and countries}

Three categories of state employed teachers - a newly qualified teacher (NQT), a teacher with five years' experience, and a teacher with 10 years' experience - were chosen for the international salary comparisons. Country choice was based on historical migration patterns where South African teachers tend to target countries such as the UK, Australia, New Zealand, Canada, Japan and the United States. Zimbabwe teacher salaries are also reviewed due to the high percentage of Zimbabwean teachers which constitute the foreign teaching workforce in SA.

\section{Teacher definitions}

The defining point for the NQT category is that the worker has a formally recognised teaching qualification. A teacher with five years' experience requires a teaching qualification and five years' experience whilst the final category of teacher requires a teaching qualification and 10 years' teaching 
experience. These definitions are easily recognised internationally and this affords for more accurate comparisons.

\section{The data}

Table 1 reports 2014/2015 salaries in national currency units for South Africa and selected foreign countries for typical high school teachers in publically funded, state schools. The chosen starting point for each country salary is a newly qualified teacher (NQT) who has obtained a four-year Bachelor of Education Degree or a three-year degree plus a post-graduate diploma. From this point of job entry in either 2014 or 2015 each country has its own salary scale and rules for progression as well as mechanisms to go beyond the basic scale, so potentially a teacher can take advantage of financial rewards through taking on more responsibilities. Only the basic scale progression is reported unless otherwise stated.

To map how a NQT might progress up a given salary scale during a typical teaching career, two other salary points are reported, which include the salary after five years and lastly the salary after 10 or more years. These were deemed appropriate markers to gain insightful monetary comparisons as a teacher gains career experience. Some countries reach the upper end of a given salary scale after 10 years, some take considerably longer.

Zimbabwe aside, all selected countries have the basic structure of one notch increment per year assuming performance is satisfactory. Countries began to diverge with regards to the requirements and speed by which a teacher can advance on higher pay scales that represent specialisation, expertise and other additional responsibilities. Salient points of such advancements and other salary scale details pertinent to each country are reported below under the relevant country heading. 
Table 1: Basic annual salaries for newly qualified through to experienced teachers for selected countries in their own national currency units (2014/2015)

\begin{tabular}{|c|c|c|c|}
\hline Country & NQT $^{1}$ & 5 years $^{2}$ & $10+$ years $^{2}$ \\
\hline $\mathbf{S A}^{3}$ & $\mathbf{R} 212,811$ & R223,674 & $\mathbf{R 2 3 5 , 0 7 7}$ \\
\hline $\mathbf{U K}^{4}$ & $£ 25,623 / £ 27,543$ & $£ 35,823 / £ 37,119$ & $£ 41,247 / £ 45,905$ \\
\hline $\mathbf{U S}^{5}$ & $\$ 35,870 / 54,310$ & $\$ 59,150$ & $\$ 69,425$ \\
\hline Australia $^{6}$ & $\$ 55,155$ & $\$ 76,318$ & $\$ 91,751$ \\
\hline Canada $^{7}$ & $\$ 44,204 / \$ 53,657$ & $\$ 54,896 / \$ 64,254$ & $\$ 67,556 / \$ 77,092$ \\
\hline $\mathbf{N} \mathbf{Z}^{8}$ & $\$ 40000 / \$ 50000$ & $\$ 63,054$ & $\$ 68,591$ \\
\hline Japan9 & $¥ 3,360,000$ & $¥ 3,479,955$ & $¥ 4,525,740$ \\
\hline Zimbabwe $^{10}$ & US\$4800 & - & - \\
\hline
\end{tabular}

NQT starter salary beginning in 2015.

Typically a teacher moves up one salary scale notch per year.

NAPTOSA (2015)

NASUWT (2015)

Sdea, Monet (2015)

AEU (2015)

BCTF (2015)

Educationworld.net (2015)

${ }_{10}^{9}$ Payscale.com (2015)

All Africa (2015). Salaries reported in US dollar.

Some figures are pairs rather than single entries. This is designed to capture the significant variation across regions or states. This is discussed further under the country headings below, but as an example, the UK offers higher salaries inside London compared to elsewhere in the UK. This gap was deemed wide enough to be of interest. Those countries that have single figures denote little variation.

\subsection{South Africa}

The basic requirement for someone to practice teaching in South Africa is to have a four-year Bachelor of Education Degree or a three-year degree plus an Advanced Diploma in Education (ADE) or a Postgraduate Certificate in Education (PGCE). The South African salary scale system is built on a series of over 200 notches. In Table 1 the minimum value is taken as the starting salary for a NQT (notch 85 ) and after 20 years, that same teacher should be on 
notch 105 at least, possibly higher depending upon additional responsibilities. Each notch upgrade represents a $1 \%$ increase in salary and usually occurs annually although there are other chances for more accelerated progressions (National Professional Teachers' Organization of South Africa (NAPTOSA), 2011). Over their teaching career, educators can move from minimum to maximum notches in the salary range for their post, or can be promoted and move to another post to enable further movement beyond the maximum (Education Labour Relations Council (ELRC), 2011). Unlike other countries reported, most South African provinces do follow the same scale although there is some evidence to show that identically qualified and experienced teachers are not on the same notch (ELRC, 2011). Table 1 shows the relevant notch amount as if each province were identical.

\subsection{UK}

Newly qualified teachers in England and Wales (outside London) start on the first tier of the main pay scale at $£ 25,623$ (NASUWT, 2015). The highest starter salary is found in the inner London area at $£ 27,543$; outer London is slightly lower (NASUWT, 2015). Once on the main pay scale with satisfactory performance, a teacher can progress to level 6 (after five years) earning $£ 35,823$ and $£ 37,119$ for outside and inner London respectively (NASUWT, 2015). There is considerable scope to go beyond the basic main pay scale and this is defined by teacher competence and the adoption of specific responsibilities (including line management of other staff) as defined in the job description. This will shift them to the upper pay scale and after $10-20$ years a classroom teacher could earn in the region of $£ 41,247$ or $£ 45,905$ for outside and inner London respectively (NASUWT, 2015).

\subsection{US}

Much variation is found across states (Teacher Portal, 2012; United States Department of Labor (US DOL), 2012). The highest salaries are generally found in California, New York, New Jersey, Alaska, Connecticut and Illinois; the lowest include Dakota, Montana and Wisconsin (Teacher Portal, 2012; US DOL, 2012). The nation's lowest and highest average salaries are found in South Dakota and California, respectively (Educationworld, 2015). Some districts in the US pay higher salaries over the first 5-10 years in an attempt to attract and retain staff. Others offer incentives such as relocation costs, housing benefits, or a signing bonus (Teacher Portal, 2012). The two figures reported in table 1 for a NQT are South Dakota and California, respectively and for higher experience, only California (Sdea, 2015; Monet, 2015). 


\subsection{Australia}

The starter salary packages for newly qualified teachers in Australia varies significantly from state to state. The highest earnings are typically reported in the Northern Territory with the lowest in Queensland. Those teachers trained abroad require their qualifications and experience validated by the relevant state body to establish the relevant starting point according to whether they are classed as 'graduate, accomplished or an expert' (Australian Education Union (AEU), 2015).

\subsection{Canada}

Teacher salaries vary significantly across the different districts that make up Canada (British Columbia Teachers' Federation (BCTF), 2015). As of 2015, a NQT would earn $\$ 44,204$ in the majority of the districts. With a relatively large increase to $\$ 47,816$ in Fort Nelson, $\$ 49,239$ in Haida Gwaii and $\$ 53,657$ in Stikine. Across the same range; a teacher with 5 years' experience would earn $\$ 54,896$ in the majority of the districts. With another relatively large increase to $\$ 59,412$ in Fort Nelson, $\$ 59,244$ in Haida Gwaii and $\$ 64,254$ in Stikine. Teachers with 10 years' experience would earn $\$ 67,556$ in the majority of the districts. With yet another relatively large increase to $\$ 71,348$ in Fort Nelson, \$71,326 in Haida Gwaii and \$77,092 in Stikine (BCTF, 2015).

\subsection{New Zealand}

The average salary for both primary and secondary teachers in New Zealand is approximately NZ\$40 000 to $\$ 50000$ dependent upon qualifications and experience with a number of allowances that recognise additional management and other role-specific responsibilities (Educationworld.net, 2015 ). On average, allowances can add about $\$ 4,000$ to a teacher's base salary (TeachNZ, 2015).

\subsection{Japan}

Japanese teaching salaries reported in Table 1 refer to remuneration for K-12 teachers, that is teachers that teach for grade 1 through to 12 or better known as the summation of primary and secondary education (Payscale.com, 2015). A NQT will earn $¥ 3,360,000$ whilst a teacher with 5 years’ experience will earn $¥ 3,479,955$ (Payscale.com 2015). The highest salary found was for a K-12 teacher with over 10 years of experience, receiving $¥ 4,525,740$ (Payscale.com,2015). 


\subsection{Zimbabwe}

Exact estimates are difficult to obtain, but Zimbabwean teachers earn around US $\$ 400$ per month, which ranks them among the lowest paid civil servants in the country (AllAfrica, 2015). Despite being rated highly across the region for their contribution to the country's high literacy rate, Zimbabwean teachers in government institutions are still among the lowly-paid in the region.

\section{Results}

The main results are based on the PPP international dollar comparisons across the selected countries (Table 2). The home salaries are presented as national currency units (NCUs) thereby allowing for easy comparisons. All PPP ratios use consumer based data collected by the IMF (IMF, 2015). 
Table 2: Teacher salaries of selected countries at US dollar market rates and PPP equivalent for three levels of teacher experience

\begin{tabular}{|c|c|c|c|c|c|c|c|c|c|}
\hline & & SA & $\mathbf{U K}$ & US & AUS & $\mathbf{C A N}$ & $\mathbf{N Z}$ & JAP & ZIM \\
\hline \multirow{10}{*}{ NQT } & $\mathrm{NCU}^{1}$ & 212,811 & 25,623 & 35,870 & \multirow[t]{2}{*}{55,155} & 44,204 & 40,000 & \multirow[t]{2}{*}{$3,360,000$} & \multirow[t]{2}{*}{4800} \\
\hline & reo & & 27,543 & 54,310 & & 53,657 & 50,000 & & \\
\hline & \multirow{2}{*}{ RAND $^{2}$} & 212,811 & 468,043 & 423,148 & \multirow[t]{2}{*}{520,207} & 430,840 & 349,748 & \multirow[t]{2}{*}{335,101} & \multirow[t]{2}{*}{56,624} \\
\hline & & & 503,115 & 640,680 & & 522,975 & 437,185 & & \\
\hline & \multirow{2}{*}{ US $(\$)^{3}$} & 18,040 & 39,807 & 35,870 & \multirow[t]{2}{*}{44,305} & 36,535 & 29,754 & \multirow[t]{2}{*}{28,413} & \multirow[t]{2}{*}{480} \\
\hline & & & 42,970 & 54,310 & & 44,349 & 37,193 & & \\
\hline & \multirow{2}{*}{$\operatorname{PPP}(\$)^{4}$} & 37,799 & 36,552 & 35,870 & \multirow[t]{2}{*}{38,814} & 35,967 & 26,596 & \multirow[t]{2}{*}{32,497} & \multirow[t]{2}{*}{238} \\
\hline & & & 39,291 & 54,310 & & 43,659 & 33,245 & & \\
\hline & \multirow{2}{*}{\multicolumn{2}{|c|}{$\begin{array}{l}\% \text { PPP }(\$) \\
\text { gap over } S A\end{array}$}} & -3.30 & -5.10 & -2.69 & -4.85 & -29.64 & -14.03 & -93.70 \\
\hline & & & 3.95 & 43.68 & & 15.50 & -12.05 & & \\
\hline \multirow[t]{10}{*}{5 yrs } & \multirow{2}{*}{$\mathrm{NCU}$} & \multirow[t]{2}{*}{223,674} & 35,823 & 59,150 & \multirow[t]{2}{*}{76,318} & 54,896 & 63,054 & \multirow[t]{2}{*}{$3,479,955$} & \multirow[t]{2}{*}{4800} \\
\hline & & & 37,119 & & & 64,254 & & & \\
\hline & \multirow{2}{*}{ RAND } & \multirow[t]{2}{*}{223,674} & 654,362 & 697,776 & \multirow[t]{2}{*}{719,811} & 535,051 & 551,325 & \multirow[t]{2}{*}{347,064} & \multirow[t]{2}{*}{56,624} \\
\hline & & & 678,036 & & & 626,260 & & & \\
\hline & \multirow{2}{*}{ US (\$) } & 18,961 & 55,653 & 59,150 & 61,305 & 45,373 & 46,903 & 29,427 & 4800 \\
\hline & & & 57,667 & & & 53,107 & & & \\
\hline & PPP (\$) & 39,729 & 51,103 & 59,150 & 53,707 & 44,667 & 41,924 & 33,658 & 2381 \\
\hline & ITI (\$) & & 52.951 & & & 52,282 & & & \\
\hline & $\%$ PPP (\$) & & 28.63 & 48.90 & 35.18 & 12.43 & 5.52 & -15.28 & -94.01 \\
\hline & gap over $S A$ & & 33.28 & & & 31.60 & & & \\
\hline $10+\mathbf{y r c}$ & $\mathbf{N C U}$ & 235,077 & 41,247 & 69,425 & 91,751 & 67,556 & 68,591 & $4,525,740$ & $4800^{5}$ \\
\hline $107 \mathrm{y} 1 \mathrm{~s}$ & 1000 & & 45,905 & & & 77,092 & & & \\
\hline & & 235,077 & 753,440 & 818,985 & 865,371 & 658,443 & 599,739 & 451,363 & 56,624 \\
\hline & RAND & & 838,525 & & & 751,387 & & & \\
\hline & US (\$) & 19,927 & 64,080 & 69,425 & 73,703 & 55,836 & 51,022 & 38,271 & 4800 \\
\hline & US (\$) & & 71,316 & & & 63,718 & & & \\
\hline & PPP (\$) & 41,754 & 58,840 & 69,425 & 64,568 & 54,968 & 45,606 & 43,772 & 2381 \\
\hline & PF( (\$) & & 65,485 & & & 62,727 & & & \\
\hline & $\% P P P(\$)$ & & 40.92 & 66.27 & 54.64 & 31.65 & 9.23 & 4.83 & -94.30 \\
\hline & gap over $S A$ & & 56.84 & & & 50.23 & & & \\
\hline
\end{tabular}

${ }_{2}^{1}$ Salary in own national currency unit.

Author calculations. South African rands, IMF (2015) (average annual market rates Sept 2014August 2015).

3 Author calculations. US dollars, x-rates.com (2015). (average annual market rates Sept 2014 August 2015). Zimbabwe remains unchanged since paid in US dollars.

${ }_{5}^{4}$ Author calculations. International dollar (purchasing power parity, PPP) (IMF, 2015).

Little or no difference in earnings is expected for more experienced Zimbabwean teachers having more than 5 years of experience. 
When South African teachers, at any level of experience, use market rates of exchange to compare foreign earnings, differences emerge ranging from oneand-a-half to approximately three times the South African salary equivalent (Table 2); Australians potentially being the highest payers. If the rand depreciates further against our selected country currencies, these salary differentials will only increase. These large differences reported in rand and US dollars could act as a strong pull factor for South African teachers to emigrate to any of the selected countries except Zimbabwe.

However, salary comparisons using market exchange rates are misleading especially when examining from the South African perspective. Agreeing with theories that exchange rates should move towards their respective PPP benchmarks, the South African rand could be seen as heavily undervalued (The Big Mac index, 2015). Recent years have seen considerable turbulence with the SA rand showing no consistent trend that might lead to significant appreciation against some of the 'harder' currencies in Table 2. As such, comparing any salaries using the rand market exchange rate will nearly always depress the rand equivalent.

The PPP adjusts for living costs and provides the appropriate comparison especially when potential migrants are comparing standards of living across countries. Salaries are converted to US PPP equivalent, i.e., international dollars, essentially to equalise the cost of living (Table 2, PPP \$). Overall results show the gap between selected country earnings and South Africa increase with experience.

Comparing newly qualified teachers' (NQTs) PPP earnings across countries gives mixed results. Compared to South Africa, some foreign NQTs can earn less, particularly those from New Zealand and Japan. However the UK, US and Canada vary according to the lower or upper salary chosen with the US providing the highest potential NQT earnings at US $\$ 54,310$ (over $40 \%$ higher than that earned in SA).

At five years of experience the results are clear. All country salaries increase but the destination salaries rise considerably faster as shown by the large positive percentage increases in PPP dollars over South Africa; the highest is for the UK at $48.90 \%$. This trend continues at the highest level of experience of 10 years or more. Even given some of the large upper and lower bounds of some overseas teacher earnings, it is shown that by the time an NQT becomes a teacher with 10 or more years of experience, all selected overseas teachers 
earn between approximately $4 \%$ to $66 \%$ more international dollars than their rand-earning South African counterparts, with the UK, US, Canada and Australia offering the highest.

In terms of international dollar earnings, Zimbabwe is showing the opposite trend. Whilst not varying with experience, Zimbabweans can potentially double their income-earning potential at all levels of reported experience by working in South Africa.

\section{Discussion}

The purpose of this study was to examine whether incomes in destination countries would act as a pull factor for those teachers looking to further their profession abroad. This study illustrates that when adjusting for cost of living differences, the PPP incomes differ less across countries compared to those same differentials calculated using market exchange rates.

Teachers' general salaries were compared by experience rather than by subject. Whilst there is little evidence that salaries are subject dependent it must be acknowledged that STEM (science, technology, engineering and maths) teachers are in particularly high demand globally and most countries face significant shortfalls in this vital area of teaching including South Africa (National Council on Teaching Quality (NCTQ), 2010; Lecher, 2013; Centre for Development and Enerprise (CDE), 2011). This is being addressed by some education departments but not necessarily through salary incentives (West, 2013; Coughlan, 2015; Gov.UK, 2015). The problem of long term retention for STEM teachers is arguably more acute relative to teachers of other subjects since STEM related skills are also in high demand outside of the teaching sector (West, 2013). Whether this can be mitigated by offering higher salaries is a point for future research. One small US district in Colorado used a more market-based approach where maths and science teachers were paid between 10-20\% more than their non-science counterparts. (Lecher, 2013). This is believed to be an isolated case and in a strongly unionised labour force, especially that experienced in South Africa, an initiative which will struggle to gain traction.

We should reiterate that potential income gains were not the only motives for international teacher mobility. Studies have consistently reported other 
reasons for working abroad, notably professional development and the opportunity for travel (Appleton, Morgan and Sives, 2006b).

Similarly the Teacher Incentive Study (2006) found that teachers value the environment in the school along with teacher salaries. That means, when attempting to reduce the numbers of teachers leaving the profession, the environment has to be conducive to help retain them. Among the groups of teachers who are most likely to leave are the more skilled and more experienced teachers. Our research supports that of Armstrong (2009) who points out that the longer workers remain in the teaching profession, the worse off they are relative to their non-teaching counterparts. It therefore becomes increasingly unattractive for teachers to remain in the profession as they gain more experience, and the financial incentives for talented teachers to remain in the teaching force become gradually smaller. Up until the age of 28 , the monthly earnings of teachers are greater than those of non-teachers in the labour market, indicating that young labour market entrants (graduates, in this case) may, on average, fare better in the teaching profession than in nonteaching professions (Armstrong, 2009).

Armstrong (2009) concludes that teaching is likely to be an attractive profession for workers at the lower end of the skills distribution curve and unattractive at the higher end. The wage structure of teachers in the South African labour market is therefore not conducive to retaining workers who may be considered to be endowed with above-average productive characteristics. Salary structures giving advantage to those entering a profession but not competitively increasing with experience, will result in teachers electing to migrate or leave the profession. The study conducted by the Mobile Task Team (MTT) (2005) affirms this by showing that most resignations were around the 30-39 age group.

The Occupational Specific Dispensation (OSD) agreement, set out in 2007, was an attempt at addressing these problems. The OSD set out to reward teachers who remained in the profession by increasing their salary bands and providing alternative career paths for teachers (ELRC, 2008).

Migration, however, should not be viewed as an absolute loss of teachers. A study conducted by Bertram et al. (2006) found that whilst $27 \%$ of respondents indicated that they were planning to teach abroad, the vast majority $(89 \%)$ said that they would be returning to South Africa. One conclusion from this study is that, rather than perceiving international teacher 
mobility as part of some permanent 'brain drain', it may be better to define it as something that is often transitional. A further study, conducted among teachers from developing countries teaching in England, found that only 38\% wanted to settle permanently.

Manik, Maharaj and Sookrajh (2006) go further and group migrant teachers into the following categories:

(a) 'Goal achievers' who exited SA on a temporary basis to achieve particular socioeconomic goals;

(b) 'Lifestyle emigrants' who exited permanently for a better quality of life with a view to starting life afresh in a new country; and,

(c) 'Transients', those with no intention of permanently settling abroad or in SA and were at ease crossing national boundaries.

Whilst the retention of teachers remains a priority, the impact of migration has been viewed qualitatively rather than quantitatively, suggesting that international teacher mobility may not impede the attainment of goals in terms of the quantity of education provided, but it may somewhat erode the quality. This affirms the notion that teacher migration may not be creating quantitative shortages of teachers, but rather results in the loss of teachers who were particularly effective. It is therefore paramount to ensure teacher quality over an absolute increase in numbers. Teacher quality is understood to depend on numerous factors, which include who is attracted to the teaching force, the incentives put in place for these individuals to perform well, and whether the best-performing teachers remain in the teaching force (Hernani-Limarino 2005).

The recruitment, performance and retention of teachers is dependent on the 'opportunity cost' of being a teacher, and the most important aspect of this opportunity cost is the wage differential between teachers and non-teachers (Hernani-Limarino, 2005). A pressing question in the economics-of-education literature is whether the remuneration offered to teachers is sufficient to guarantee acceptable teacher quality by attracting, recruiting and retaining the most 'attractive' individuals, in terms of productive characteristics. 


\section{Conclusion}

Migration peaked in the late 1990s and early 2000s due to a number of factors including government policy and the prospect of a higher income abroad. Demand for foreign teachers has been falling as improvements in pay have increased the inflow of native teachers whilst regulations imposed on foreigners have made working abroad more difficult.

It has been argued that international migration has not led to harmful shortages of teachers in South Africa, but rather 'creamed off' the more skilled and experienced teachers. Research has supported this notion and suggested that SA teachers receive much smaller returns on additional years of education, experience or tenure, which may serve as a disincentive to invest further in their own human capital, or to stay in the teaching profession. This research has stated that entry-level teachers are at the top end of the earnings distribution, whereas the more skilled and experienced teachers are relatively underpaid in relation to their foreign counterparts. This compression of wages could mean that teachers with the most favourable sets of labour market characteristics will be more inclined to leave the teaching profession, whereas those with the least favourable endowments will find it attractive to stay (Van der Berg and Burger, 2010). It is the more experienced and skilled teachers in particular that policy makers need to pay careful attention to, and attempt to create an attractive, healthy and supportive environment for local teachers or run the risk of losing them to international recruitment agencies offering lucrative salaries. Failing this, one can conclude that the international mobility of teachers may not adversely affect the provision of education in the country but rather the quality of education provided as the more experienced teachers are lured abroad or out of the profession. 


\section{References}

Australian Education Union (AEU), 2015. Current salary rates. Australian Education Union. Accessed 8 October 2015. http://www.aeusa.asn.au/teachers rates updated 1 july 2015.pdf?lid=14

All Africa. 2015. Zimbabwe: Zim Teachers Among Lowest Paid in the Region. Accessed 8 October 2015.

http://allafrica.com/stories/201505140998.html

Amity. 2012 Accessed 8 October.

http://www.amityteachers.com/english-teaching-jobs-requirements/requireme nts-contract-benefits/

Arends, F. and Phurutse, M. 2009. Beginner teachers in South Africa: school readiness, knowledge and skills. Cape Town: HSRC Press.

Armstrong, P. 2009. Teacher pay in South Africa: how attractive is the teaching profession? Stellenbosch Economic Working Papers: 04/09. Stellenbosch, South Africa: Stellenbosch University.

Asmal, K. 2001. UK behind SA brain drain. BBC News, 16 February, 1-2.

Appleton, S., Sives, A. and Morgan, W.J. 2006a. The impact of international teacher migration on schooling in developing countries - the case of Southern Africa. Globalisation, Societies and Education, 4(1): pp.121-142.

Appleton, S., Morgan, W.J. and Sives, A. 2006b. Should teachers stay at home? The impact of international teacher mobility. Journal of International Development, 18: pp.771-786.

British Columbia Teachers' Federation (BCTF) Research. 2015. Canadian teacher salary rankings: provinces and territories. Accessed: 8 October 2015. https://www.bctf.ca/SalaryAndBenefits.aspx?id=14758

Bertram, C., Appleton, S., Muthukrishna, N. and Wedekind, V. 2006. The career plans of newly qualified South African teachers. South African Journal of Education, 26(1): pp.1-13. 
Caravatti, M., Lederer, S., Lupico, A., Meter, N. 2014. Getting teacher migration \& mobility right. Education International. Brussels, Belgium.

Centre for Development and Enterprise (CDE). Value in the classroom: the quantity and quality of South Africa's teachers. In Depth No.11, Johannesburg, South Africa, September, 2011.

Commonwealth Secretariat. 2010. Fair treatment of migrant teachers: new qualifications table opens the door. Accessed: 25 July, 2013. From: http://secretariat.thecommonwealth.org/news/190663/163077/220522/240210 fairtradeforteachers.htm

Coughlan, S. 2015. Cameron's $£ 15,000$ for maths and science teachers. BBC News. Accessed: 5 October. http://www.bbc.com/news/education-31825454

Department of Basic Education (DBE). 2013. PERSAL database December 2012. Pretoria, South Africa: Department of Basic Education.

Department of Education (DoE). 2006. The National Policy Framework for teacher education and development in South Africa. "More teachers; better teachers". Pretoria, South Africa: Department of Education.

De Villiers, J.J.R. 2004. South African teachers in United Kingdom schools: expectations and experiences. Journal of Educational Studies, 3(1): pp.49-66.

Educationworld.net. 2015. World of education. Teacher salary information. Accessed: 8 October 2015.

http://www.educationworld.net/teacher salaries.html

Education Labour Relations Council (ELRC). 2008. Framework for the establishment of an occupation specific dispensation (OSD) for educators in public education.

http://www.elrc.org.za/sites/default/files/documents/CollectiveAgreementNo1 of2008.pdf

Education Labour Relations Council (ELRC). 2011. Revised salary structure proposals. June 2011. Report prepared by the Centre for Education Policy Development. http://www.elrc.org.za/sites/default/files/documents/CollectiveAgreementNo1 of2008.pdf 
Forde, F. 2007. Don't fret if we use Zim teachers, says Hindle. Pretoria News, 12 January 2007.

Gilbey, V. 2001. Teaching profession being replenished. Daily News, 2 August 2001, p.4.

Gov.UK, 2015. Major push to get more maths and physics teachers into our classrooms. Prime Minister's Office, Department of Education.

Accessed: 6October 2015.

https://www.gov.uk/government/news/major-push-to-get-more-maths-and-ph ysics-teachers-into-our-classrooms

Harichunder, S. 2001. Chicken run ruffles feathers. Sunday Tribune, 2 September 2011.

Jansen, H. 2002. Britte sukkel erg met dissipline in hul skole. Rapport.

7 March. http://152.111.1.87/argief/berigte/rapport/2002/04/28/4/14.html

Hernani-Limarino, W. 2005. "Are teachers well-paid in Latin America and the Caribbean?". In Vega, E. (Ed.), Incentives to improve teaching: lessons from Latin America. Washington DC: World Bank, pp.63-102.

International Monetary Fund (IMF). 2015. World Economic outlook database, October 2015. Report generated online. Accessed: 10 October 2015.

Kok, P., Gelderblom, D., Oucho, J. and Van Zyl, J. (Eds). 2006. Migration in South and Southern Africa: dynamics and determinants. Cape Town: HSRC Press.

Lecher, C. 2013. School district to pay science teachers more than English teachers. Popular Science. Accessed: 6 October.

http://www.popsci.com/science/article/2013-06/colorado-school-district-willstart-paying-science-teachers-more-english-teachers.

Louw, R. 2001a. Overseas recruits to make up skills deficit. Southern Africa Report, 19(17): pp.11-12.

Louw, R. 2001b. Brain drain hits South Africa hard. Southern Africa Report, 19(27): pp.11-12. 
Makina, D. 2007. Survey of profile of migrant Zimbabweans in South Africa: a pilot study. Pretoria: University of South Africa.

Manik, S., Maharaj, B. and Sookrajh, R. 2006. Globalisation and transnational teachers: South African teacher migration to the UK. Migracijske i etničke teme, 22(1-2): pp.15-33.

Mkhize, T. 2004. Commonwealth bid to retain teachers. Sunday Times, 22 August, p.2.

Morgan, W.J., Sives, A. and Appleton, S. 2006. Report of the teacher mobility, 'brain drain', labour markets and educational resources in the Commonwealth. London: Commonwealth Policy Studies Unit.

Mobile Task Team (MTT). 2005. Educator attrition and mortality in South Africa. Centurion: Report Prepared for the ELRC.

Monet. 2015. Modesto city schools 2014-2015 certificated salary schedule. Accessed 9 October 2015.

https://www.monet.k12.ca.us/documents/CertificatedSalarySchedule.pdf

Mosala, S.M.G. 2008. The work experience of Zimbabwean migrants in South Africa. Issues paper, 33. Harare: International Labour Organization (ILO) Sub-Regional Office for Southern Africa.

Mugano, L. 2010. Teacher supply and demand in South Africa. PhD diss., University of Pretoria, South Africa.

Naidu, E. 2001. The Brits are taking our teachers. The Teacher, 30 April, p.9.

National Professional Teachers' Organization of South Africa (NAPTOSA) 2011. Educators - General salary adjustment. Translation Table. (Government Gazette 34559, 2011). Pretoria: Government Printer.

National Professional Teachers' Organization of South Africa (NAPTOSA). 2015. Educator/lecturers salary scales. Accessed 8 October 2015. http://www.naptosa.org.za/index.php/salary-issues/1355-educators-lecturers-7 -salary-increase-effective-1-april-2015 
NASUWT. 2015. The Teachers' Union 2014 Salary Scales The Fringe, Outer London and Inner London. Accessed 8 October 2015. http://www.nasuwt.org.uk/consum/groups/public/@,salariespensionscondition s/documents/nas download/nasuwt 012875.pdf

New Teachers. 2012. Pay scales explained. Accessed: 13 September. http://newteachers.tes.co.uk/news/pay-scales-explained/23507

NewsdzeZimbabwe. 2012. New teachers, new nurses pay - \$419 a month. Accessed: 9 September 2013. http://www.newsdzezimbabwe.co.uk/2012/01/new-teachers-nurses-pay-419month.html

National Council on Teaching Quality (NCTQ). 2010. The all-purpose science teacher: an analysis of loopholes in state requirements for high school science teachers. Washington, USA: National Council on Teaching Quality.

Ochs, K. 2003. A summary of 'Teaching at risk' - teacher mobility and loss in Commonwealth member states. A study commissioned by the Commonwealth Secretariat Education Section at the request of Ministers of Education of the Commonwealth Caribbean. London: Commonwealth Secretariat.

Payscale.com. 2015. Pay scale for K-12 teachers: Japan. Accessed: 8 October 2015.

http://www.payscale.com/research/JP/All K-12 Teachers/Salary\#by Years Experience

Peltzer, K., Shisana, O., Zuma, K., Van Wyk, B. and Zungu-Dirwayi, N. 2009. Job stress, job satisfaction and stress-related illnesses among South African educators. Stress and Health 2009, 25(3): pp.247-257. (Article first published online : 9 DEC 2008, DOI: 10.1002/smi.1244.)

Ranga, D. 2015. Gender differences in the Migration of Zimbabwean teachers to South Africa. Eastern Africa Social Science Research Review, 31(1): pp.43-62.

Rasool, F., Botha, C. and Bisschoff, C. 2012. Push and pull factors in relation to skills shortages in South Africa. Journal of Social Sciences, 30(1):

pp.11-20. 
Shalem, Y. and Hoadley, U. 2009. The dual economy of schooling and teacher morale in South Africa. International Studies in Sociology of Education, 19(2): pp.119-134.

Shisana, O., Peltzer, K., Zungu-Dirwayi, N. and Louw, J. (Eds). 2005. The health of our educators: a focus on HIV/AIDS in South African schools. Cape Town: HSRC Press.

Sibanda. N. 2013. Teachers pressure Mugabe to pay promised PDL salaries. Accessed: 28 August. http://www.thezimbabwean.co/2013/08/teachers-pressure-mugabe-to-pay/

Smithers, A. and Robinson, P. 2001. Teachers leaving. Liverpool: University of Liverpool. Department of Education. Centre for Education and Employment Research.

South African Council for Educators (SACE). 2010. A review of teacher demand and supply: identifying gaps and the role of SACE. July 2010. http://www.sace.org.za/upload/files/A\%20review\%20on\%20teacher\%20dema nd\%20and\%20supply\%20in\%20South\%20Africa.pdf

South African Council for Educators (SACE). 2011. Teacher migration in South Africa: Advice to the Ministries of Basic and Higher Training. June 2011. www.sace.org.za/upload/files/TeacherMigrationReport 9June2011.pdf

Sdea. 2015. Salary Schedule and Provision 2014-2015. Accessed 9 October 2015. http://www.sdea.org/assets/document/SD/Yankton NA 2014-17.pdf

Teacher Portal. 2012. Teacher salary data by state. Accessed: 12 September.

TeachNZ. 2015. Teaching in New Zealand. Accessed: 8 October 2015. https://www.teachnz.govt.nz/teaching-in-new-zealand/salaries/

The Big Mac index. 2015. The Economist. Accessed: 10 October 2015. http://www.economist.com/content/big-mac-index

United States Department of Labor (US DOL). 2012. Bureau of Labor statistics. Accessed: 10 September. http://www.bls.gov/oes/CURRENT/oes252031.htm\#\%282\%29 
Van der Berg, S. and Burger, R. 2010. Teacher pay in South Africa.

Stellenbosch Economic Working Papers: 26/10. Stellenbosch, South Africa:

Stellenbosch University.

Van Leeuwan, F. 2001. Growing teacher shortage, The Teacher, 5 August, p.18.

Wentzel, M. and Tlabela, K. 2006. Historical background to South African migration. In Kok, P., Gelderblom, D., Oucho, J. and Van Zyl, J. Migration in South and Southern Africa: dynamics and determinants. Cape Town: HSRC Press, pp.71-96.

Wentzel, M., Viljoen, J. and Kok, P. 2006. Contemporary South African migration patterns and intentions. In Kok, P., Gelderblom, D., Oucho, J. and Van Zyl, J. Migration in South and Southern Africa: dynamics and determinants. Cape Town: HSRC Press, pp.171-204.

West, M.R. 2013. Do maths and science teachers earn more outside of education. Brookings, Education. Accessed 5 October 2015.

http://www.brookings.edu/research/papers/2013/04/17-math-science-teachers -west

X-rates.com. 2015. Monthly average exchange rate calculator. Accessed: 14 October 2015.

Gavin George

HEARD - Health Economics and HIV and AIDS Division (HEAD)

University of KwaZulu-Natal

Durban

georgeg@ukzn.ac.za

Bruce Rhodes

School of Accounting, Economics and Finance

University of KwaZulu-Natal

Durban, South Africa.

rhodesb@ukzn.ac.za 
